\title{
Analisis Psikopatologi Sindroma Depresi Pecandu Narkoba Kini Abstinen yang Mengalami Stroke
}

\author{
Lainatul Mudzkiyyah \\ Fakultas Psikologi dan Kesehatan, UIN Walisongo Semarang \\ m_lainatul@gmail.com
}

\begin{abstract}
This study aimed to uncover how to analyze psychopathology in depth about drug addicts with depression syndrome after abstinence from substances and suffer a stroke. This study involved one (1) male subject, aged 22 years, drug addicts are now abstinent in drug rehabilitation treatment, experiencing depression, and stroke due to substances. This study used a qualitative approach to case studies. Data extraction in this study used observation, in-depth interviews, medical records, and psychological tests such SPM (Scale Progressive Matrick), Graphics (BAUM, DAP, HTP, WTZ), BDI II. The results of this study indicated that introverted personality types, low cognitive abilities, family neglect contributed to depression syndrome with poor prognosis. Other than that, experiencing depression was not caused by abstinence of substances but because of psychological factors.
\end{abstract}

Keyword: Psychopathology, Depression, Drug addicts

\begin{abstract}
Abstrak. Penelitian ini ingin mengungkap bagaimana analisa psikopatologi secara mendalam pecandu narkoba dengan sindroma depresi setelah abstinen dari zat dan menderita stroke. Penelitian ini melibatkan satu (1) subjek laki-laki, berusia 22 tahun, pecandu narkoba kini abstinen dalam perawatan rehabilitasi narkoba, mengalami depresi, dan stroke akibat zat. Penelitian ini menggunakan pendekatan kualitatif dengan studi kasus. Penggalian data pada penelitian ini menggunakan observasi, wawancara mendalam, rekam medis, disertai dengan tes psikologi berupa SPM (Scale Progressive Matrick), Grafis (BAUM, DAP, HTP, WTZ), BDI II. Hasil penelitian ini menunjukkan bahwa tipe kepribadian introvert, kemampuan kognitif yang rendah, pengabaian keluarga turut menyumbangkan sindroma depresi dengan prognosi buruk. Selain itu, depresi yang dialami subjek bukan disebabkan oleh putusnya zat akan tetapi karena faktor psikologis.
\end{abstract}

Keyword: Psikopatologi, Depresi, Pecandu narkoba 


\section{Pendahuluan}

Kajian kasus narkoba dilakukan pada pecandu narkoba yang kini abstinen di rumah rehabilitasi narkoba. Subjek merupakan seorang laki-laki berusia 22 tahun. Subjek mulai menyalahgunakan zat sejak kelas 3 SMP. Kemudian, Subjek putus sekolah di kelas 2 SMK. Akibat penyalahgunaannya, subjek mengalami overdosis yang berdampak stroke. Selama empat bulan terakhir, subjek terlihat murung, tidak bersedia mengikuti kegiatan, dan hanya berdiam di kamar. Subjek juga terlihat minim bicara, bahkan suaranya sangat lirih hampir tidak terdengar. Selain itu, subjek terlihat enggan bergaul dengan residen (sebutan untuk peserta rehabilitasi narkoba) lain. Nafsu makan subjek juga menurun. Subjek juga pernah melakukan dua kali percobaan bunuh diri selama menjalani rehabilitasi. Selain itu, subjek juga mengalami kesulitan tidur. Kondisi fisik subjek terlihat memprihatinkan. Sekujur kulit tangan dan kaki dipenuhi penyakit kulit seperti koreng dan kudis. Kuku-kuku dan sela-sela jari subjek juga terlihat kotor tidak terawat.

Subjek diikutkan kegiatan rehabilitasi narkoba oleh budhenya pasca overdosis. Namun, tiga bulan setelahnya budhe subjek meninggal dunia. Pasca meninggalnya budhe subjek, tidak ada satupun keluarga besar yang bersedia menerima subjek. Bahkan, masyarakat di kampung subjek juga enggan menerima subjek kembali.

Paparan kasus di atas memberikan gambaran latar belakang kasus penyalahgunaan narkoba dari partisipan. Akibat penyalahgunaan ini dapat menimbulkan resiko ketergantungan akan zat, overdosis, komplikasi penyakit, hingga kematian (Sitorus, 2014). Kasus penyalahgunaan narkoba selain merugikan individu juga merugikan negara. Negara mengalami kerugian yang amat besar baik dari segi materi maupun non materi. Pada tahun 2017, estimasi biaya kerugian ekonomi akibat narkoba sebesar Rp.84,7 Triliyun dengan Rp. 77,42 Triliyun untuk kerugian pribadi dan Rp. 7,72 Triliyun untuk biaya sosial (BNN, 2017). Sementara kerugian yang tak ternilai harganya adalah rusaknya kualitas sumber daya manusia (SDM) sebagai generasi penerus bangsa.

Pecandu dalam masa rehabilitasi rentan mengalami gejala depresi (Afriani, 2015). Pecandu narkoba dengan gangguan depresi memiliki tingkat resiko lebih tinggi untuk melakukan percobaan bunuh diri (Danielson, et al, 2003; Espada, et al, 2011). Penelitian tersebut menunjukkan bahwa 31\% laki-laki dan 75\% perempuan memiliki tingkatan ide bunuh diri yang tinggi. Sementara, 28\% laki-laki dan 61\% perempuan memiliki upaya untuk melakukan bunuh diri meskipun sedang mendapatkan perawatan penanganan ketergantungan narkoba (Danielson, et.al, 2003). Gejala-gejala utama depresi dapat diketahui melalui afek yang depresif, tampak kehilangan minat dan kegembiraan, terlihat rasa lelah yang nyata meskipun dengan sedikit kerja serta menurunnya aktivitas (Maslim, 
Philanthrophy Journal of Psychology

Vol 2 Nomor 1 (2018), 1-10

ISSN 2580-6076 (Print), ISSN 2580-8532 (Online)

2013). Menurut Mudzkiyyah dkk (2014) para pecandu narkoba yang mengikuti rehabilitasi memiliki mood yang buruk seperti anhedonia, frustrasi, kecemasan, serta perasaan-perasaan bersalah (baik persaan bersalah kepada Tuhan, kepada keluarga, dan lingkungan masyarakat). Situasi-situaasi tersebut yang secara tidak langsung membuat para pecandu kembali kepada penyalahgunaan zat sebagai penyelesaian dari masalahannya.

Melihat dinamika pecandu narkoba yang begitu kompleks, peneliti ingin mengetahui bagaimana analisis psikopatologi episode depresi pecandu narkoba secara mendalam di lihat dari riwayat keluarga, kepribadian, dan kemampuan kognitif dalam menyelesaikan masalah.

\section{Metode}

Penelitian ini menggunakan pendekatan kualitatif dengan metode studi kasus untuk menggali informasi yang mendalam tentang dinamika psikis di balik gangguan psikologis (Kahija, 2017). Partisipan yang terlibat yaitu satu subjek laki-laki berusia 22 tahun, penyalahguna NAPZA kini abstinen dari zat dan sedang dalam perawatan rehabilitasi, mengalami stroke akibat overdosis, dan mengalami sindrom depresi. Penentuan subjek ini menggunakan teknik purposive sample (sample bertujuan). Hal ini dikarenakan pemilihan sampel sesuai dengan yang dikehendaki untuk kasus unik dan sulit mengambil sampel serta membutuhkan investigasi mendalam (Kurniawan \& Sulistyarini, 2017).

Penggalian data dilakukan dengan wawancara mendalam, observasi, rekam medis, tes psikologi menggunakan SPM untuk daya kognitif, BDI-II (Beck Depression Inventory) untuk sindrom depresi, dan tes grafis (BAUM, DAP, HTP, WTZ) untuk karakteristik kepribadian. Wawancara mendalam juga dilakukan kepada significant other seperti keluarga subjek, dan konselor adiksi yang merawat subjek sebagai informan. Informan tersebut merupakan orang yang mengetahui dan memiliki hubungan dengan subjek serta mengetahui permasalahan yang ingin diteliti tanpa ada kecenderungan untuk menjelekjelekkan atau bersikap netral (Kurniawan \& Sulistyarini, 2017).

Analisis data menggunakan data deskriptif yang terintegrasi dari berbagai sumber baik dari hasil observasi, wawancara dengan subjek, informan significant other, hasil psikotes (tes psikologi), dan rekam medis. 
Philanthrophy Journal of Psychology

Vol 2 Nomor 1 (2018), 1-10

ISSN 2580-6076 (Print), ISSN 2580-8532 (Online)

\section{Hasil}

Hasil psikotes yang didapatkan dari asesmen kepada subjek dapat dilihat pada tabel.1 berikut:

\section{Jenis Tes}

\section{Hasil dan Interpretasi}

SPM (Standard Hasil tes inteligensi subjek berada pada row score percentile 0.25. Hasil ini Progressive menandakan kemampuan kognitif subjek masuk ke dalam kategori grade IV. Matric) Artinya, kemampuan kognitifnya tergolong di bawah rata-rata di bandingkan dengan kelompok usianya.

Tes BDI-II Subjek masuk dalam kategori depresi sedang dimana subjek memiliki skor 28 dengan 14 poin pada aspek somatik dan 14 poin pada aspek kognitif.

\begin{tabular}{|lrl|}
\hline Tes & Grafis & Klien merupakan personal yang introvert, menarik diri, dan lebih suka \\
(BAUM, & DAP, & menyelesaikan masalah dengan dirinya sendiri. Selain itu, konsep dirinya \\
& juga kabur. Subjek tidak mampu mengidentifikasikan dan memproyeksikan \\
& dirinya. \\
& Klien juga kabur dalam mempersepsi figur ayah. Selain itu, klien juga \\
& memberikan penilaian yang negatif terhadap figur ibu. Fungsi ibu dirasa \\
& kurang. Subjek merasa tidak diterima oleh ibu. Dalam fungsinya di dalam \\
& keluarga, Subjek merasa bahwa dirinya kurang diperhatikan dan kurang \\
& berharga. \\
& Subjek kurang mampu mengekspresikan emosi dan perasaannya. Subjek \\
& juga menunjukkan kemampuan problem solving dan analisis masalah yang \\
& buruk. Subjek tidak menunjukkan minat dalam merespon stimulus yang ada \\
& di sekitar dirinya. Subjek menunjukkan minimnya energi, serta tidak ada \\
& dorongan dalam menghadapi persoalan hidup. Selain itu, subjek juga \\
& menunjukkan masalah dalam penempatan diri dan penyesuaian dirinya.
\end{tabular}


Philanthrophy Journal of Psychology

Vol 2 Nomor 1 (2018), 1-10

ISSN 2580-6076 (Print), ISSN 2580-8532 (Online)

\section{Analisis Keluarga}

Riwayat keluarga subjek dapat diketahui dari analisis bagan genogram. Bagan genogram tentang keluarga subjek dapat di lihat dari bagan 2, sebagai berikut.
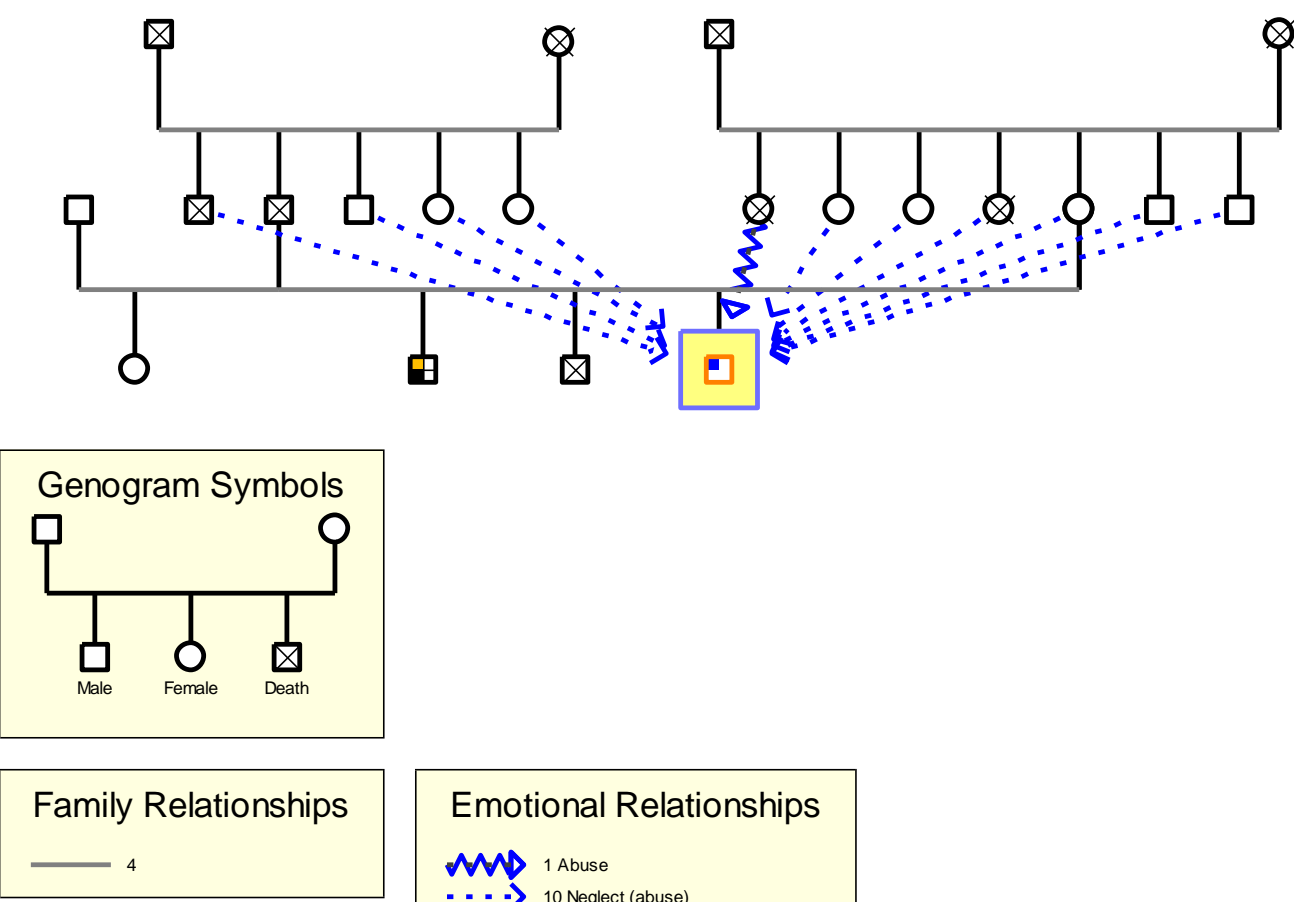

Emotional Relationships

$M 1$ Abuse

- - > 10 Neglect (abuse)

$$
\begin{aligned}
& { }^{20} \\
& \text { 日 }{ }^{1 \text { HI / AIDS }}
\end{aligned}
$$

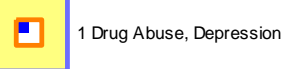

Bagan 2. Genogram di atas menjelaskan bahwa subjek merupakan seorang dari empat bersaudara. Saudara-saudara subjek yaitu satu saudara perempuan (tiri), satu saudara laki-laki yang sudah meninggal, dan satu lagi saudara laki-laki yang juga pecandu narkoba, dan penyintas HIV. Ayah kandung subjek sudah meninggal dunia. Kemudian, ibu subjek menikah kembali. Subjek mendapatkan pengabaian dari ibu. Selain itu, subjek juga mendapatkan kekerasan secara psikologis dari budhenya. Subjek juga mendapatkan pengabaian dan penolakan dari seluruh keluarga besarnya baik dari pihak ayah maupun ibu. 
Philanthrophy Journal of Psychology

Vol 2 Nomor 1 (2018), 1-10

ISSN 2580-6076 (Print), ISSN 2580-8532 (Online)

Analisis Paradigma Psikopatologi

Analisis psikopatologi pecandu narkoba yang abstinen karena rehabilitasi dan saat ini mengalami episode depresi dapat dilihat pada bagan 3 di bawah ini!

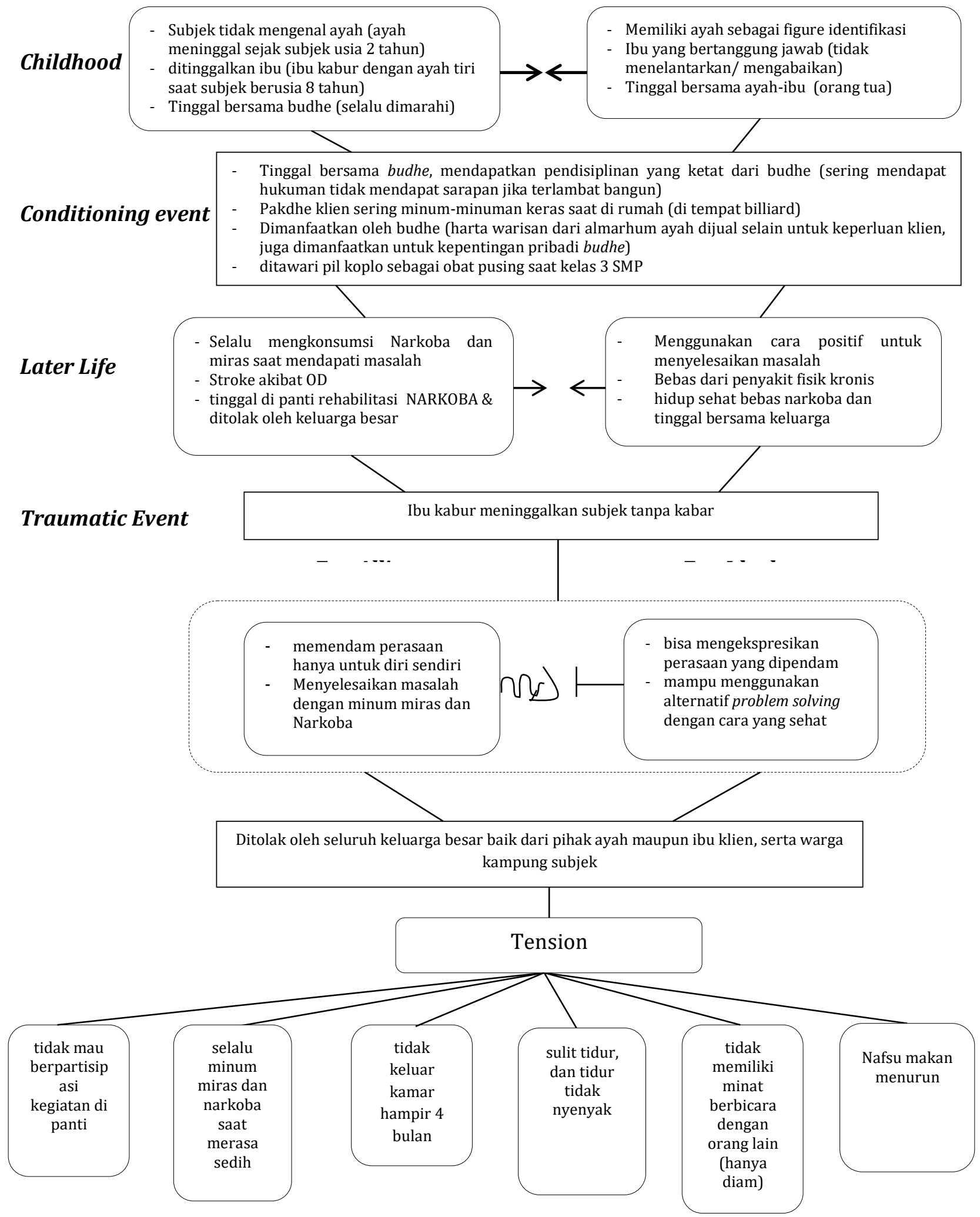

Bagan 2. Analisis Psikopatologi 
Philanthrophy Journal of Psychology

Vol 2 Nomor 1 (2018), 1-10

ISSN 2580-6076 (Print), ISSN 2580-8532 (Online)

Penegakan Diagnosis Multiaksial

Diagnosis multiaksial pada subjek ini dapat dilihat pada tabel 2, sebagai berikut!

\begin{tabular}{ll}
\hline Aksis I & $\begin{array}{l}\text { F1x.21 sindrom ketergantungan kini abstinen tetapi dalam situasi yang } \\
\text { terlindungi seperti komunitas terapeutik } \\
\end{array}$ \\
& F32.1 sindrom depresi sedang sebagai gangguan komorbid \\
\hline Aksis II & Kepribadian Introvert \\
Aksis III & Stroke yang mengakibatkan kelumpuhan pada tangan dan kaki kanan \\
Aksis IV & Diterlantarkan ibu, mendapatkan penolakan dari keluarga besar, dan \\
& lingkungan masyarakat \\
Aksis V & GAF 60 - 51 gejala sedang (moderate), disabilitas sedang \\
\hline
\end{tabular}

\section{Prognosis}

Prediksi tingkat kesembuhan subjek dengan gangguan yang dideritanya dapat diketahui dari prognosis pada tabel 3, sebagai berikut!

\begin{tabular}{|c|c|c|c|c|}
\hline \multirow[t]{2}{*}{ No } & \multirow[t]{2}{*}{ Kategori } & \multirow[t]{2}{*}{ Keterangan } & \multicolumn{2}{|c|}{ Prognosis } \\
\hline & & & Baik & Buruk \\
\hline & Hasil diagnosis & $\begin{array}{l}\text { Sindrom ketergantungan } \\
\text { abstinen dalam lingkungan terlindung } \\
\text { disertai dengan sindrom depresi } \\
\text { sebagai komorbid }\end{array}$ & & $\checkmark$ \\
\hline 2. & Perjalanan penyakit & Sejak SMP kelas 3 (7 tahun) & & $\checkmark$ \\
\hline 3. & Onset & 15 tahun & & $\checkmark$ \\
\hline 4. & Status marital & Belum menikah & & $\checkmark$ \\
\hline 5. & Stressor & Jelas : Keluarga & & $\checkmark$ \\
\hline 6. & Dukungan keluarga & Tidak ada & & $\checkmark$ \\
\hline 7. & Faktor keturunan & Tidak ada & $\checkmark$ & \\
\hline & Insight & Tidak ada & & $\checkmark$ \\
\hline & Gangguan Organik & Tidak ada & $\checkmark$ & \\
\hline & Respon terhadap NAPZA & Positif & & $\checkmark$ \\
\hline & Perilaku koping & Menghindar & & $\checkmark$ \\
\hline & Kepribadian premorbid & Tidak ada & $\checkmark$ & \\
\hline & Kemampuan diri untuk sembuh & $\begin{array}{l}\text { Tidak kooperatif (belum ada } \\
\text { kesadaran untuk mengikuti therapy) }\end{array}$ & & $\checkmark$ \\
\hline & & & 3 & 10 \\
\hline
\end{tabular}

Tabel 3. Prognosis Subjek

\section{Diskusi}

Subjek adalah individu dengan masa lalu yang penuh dengan masa traumatik. Peristiwa traumatik yang dialami subjek di masa lalu menjadikan subjek mengembangkan kecemasankecemasan dasar dan permusuhan. Semasa kanak-kanak, subjek banyak mengalami peristiwaperisiwa yang tidak menyenangkan seperti ayah yang sudah meninggal disaat subjek kecil. Oleh karena itu, subjek tidak mengenal figur ayah. Ibu juga pergi meninggalkan subjek tanpa ada 
Philanthrophy Journal of Psychology

Vol 2 Nomor 1 (2018), 1-10

ISSN 2580-6076 (Print), ISSN 2580-8532 (Online)

kejelasan kabar. Sementara itu, subjek harus tinggal bersama budhe karena nenek yang mengasuhnya telah meninggal dunia. Kecemasan dasar yang dimiliki subjek kemudian berkembang pada kecenderungan-kecenderungan neurotik (Alwisol, 2012). Gambaran permusuhan dasar subjek dihasilkan dari perasaan kanak-kanak terhadap penolakan atau pengabaian orang tua. Dalam hal ini, subjek merasa diabaikan oleh ibu dengan tidak memberikan kabar saat meninggalkan klien. Sementara proses untuk mengatasi kecemasan dasar tersebut, subjek kemudian melakukan pertahan diri dengan gerakan kompulsif menjauh dari orang lain. Perilaku menjauh dari orang lain muncul pada kepribadian subjek yang suka menyendiri.

Subjek menunjukkan sikap dan kepribadian yang sulit untuk dipahami. Subjek cenderung menutup diri untuk mengkomunikasikan keinginan dirinya baik kepada diri sendiri maupun kepada orang lain. Horney (Feist \& Feist, 2008) mengungkapkan bahwa seseorang yang menyelesaikan konflik dasar perasaan terisolasi, akan bersikap menarik diri dan mengadopsi kecenderungan neorotik yang disebut bergerak menjauh dari orang lain. Strategi ini adalah ekspresi dari kebutuhan-kebutuhan atas privasi, independensi, dan kepuasan diri. Kebutuhan atau strategi ini menjadi neurotik jika orang memuaskan diri dengan meletakkan secara kompulsif jarak emosional diantara diri mereka dan orang lain. Banyak penderita neurotik menemukan bahwa upaya menyesuaikan diri dengan orang lain adalah hal sia-sia. Mereka seringkali membangun dunia mereka sendiri dan mengusir jauh-jauh dari setiap orang yang berusaha mendekati dunianya.

Penekanan pada kecemasan yang dikembangkan subjek dalam dirinya berujung pada pengembangan konflik-konflik intrapsikis. Konflik yang berangkat dari tema diabaikan dan dikhianati oleh figur ibu kembali berulang pada figur budhe yang merawat dirinya. Konflik tersebut berasal dari sikap budhe yang memanfaatkan kondisi klien dengan menjual harta warisan dari ayah klien untuk kepentingan pribadi. Subjek merasa terombang-ambingkan dan merasa kebingungan dengan sikap dan perlakuan yang diterima. Subjek merasa butuh disayangi oleh figur ibu namun subjek juga merasa ditipu oleh figur ibu tersebut. Kehadiran budhe yang seharusnya merawat subjek dengan penuh kasih sayang layak ibu, ternyata memanfaatkan kondisi ketidakberdayaan subjek. Tekanan-tekanan batin yang dialami subjek menjadikan konflik batin yang tidak berujung pada penyelesaian. Proses-proses intrapsikis yang lahir dari pengalaman-pengalaman subjek kemudian melahirkan konflik berupa self-hatred (kebencian pada diri sendiri).

Kebencian-kebencian subjek terhadap diri sendiri diekspresikan dengan perilakuperilaku destruktif seperti menyakiti dan menghancurkan diri sendiri (Alwisol, 2012). Perilakuperilaku subjek yang tampak adalah perilaku meminum alkohol, dan mengkonsumsi obatobatan terlarang (NAPZA). Perilaku mengkonsumsi pil koplo, benzodiazepin menjadikan subjek 
Philanthrophy Journal of Psychology

Vol 2 Nomor 1 (2018), 1-10

ISSN 2580-6076 (Print), ISSN 2580-8532 (Online)

over dosis yang berakibat pada kerusakan sistem syaraf yang ada di otak yang berdampak pada stroke. Akibat stroke tersebut, subjek mengalami kelumpuhan pada tangan dan kaki bagian kiri. Kebencian terhadap diri klien juga semakin meningkat setelah subjek mendapati kondisinya lumpuh.

Kondisi subjek dengan kecacatan fisik, keluarga berantakan, diabaikan oleh semua keluarga besar, dihianati oleh budhe membuat subjek semakin frustrasi. Sementara itu, dukungan dari keluarga, pasangan, orangtua menjadi penentu keberhasilan pecandu narkoba dalam meningkatkan kualitas hidupnya selama menjalani rehabilitasi (Noviarini, dkk., 2013). Rasa frustrasi yang ditunjukkan subjek adalah menarik diri dari lingkungan sosialnya, berdiam diri di kamar, serta sangat jarang berbicara dengan resident lain. Rasa permusuhan juga semakin meningkat karena subjek tidak bisa mengekspresikan perasaan-perasaannya. Perasaan-perasaan marah, benci kepada ibu tertumpuk di dalam diri tanpa ada pengekpresian. Selain itu rasa benci dan marah juga dirasakan saat subjek berinteraksi dengan budhe. Perasaan-perasaan bermusuhan yang ditekan menjadikan konflik intrapsikis dan kebingungan atas dirinya.

Karakteristis subjek dengan tipe kepribadian yang introvert juga turut mendukung sindroma depresi subjek. Supriani (2011) dalam penelitiannya juga menjelaskan bahwa tipe kepriadian introvert dengan kurangnya dukungan sosial menjadikan episode depresi pasien semakin berat. Ditambah lagi dengan kapasitas kemampuan kognitif di bawah rata-rata, hal tersebut membuat subjek kurang mampu menyelesaikan permasalahan dengan baik. Menurut Azwar (2002), tingkat kemampuan berfikir seseorang berpengaruh terhadap penyelesaian masalah baik yang dihadapi langsung maupun untuk mengantisipasi masalah-masalah yang akan datang.

\section{Simpulan}

Sindroma depresi subjek yang dialami selama menjalani rehabilitasi bukan disebabkan karena abstinen dari zat akantetapi disebabkan karena muatan psikologis. Pemicu tercetusnya adalah penolakan seluruh keluarga besar serta masyarakan di kampungya. Selain itu, riwayat kehidupan yang penuh traumatik, kemampuan kognitif yang rendah, kecenderungan kepribadian introvert serta kelumpuhan anggota tubuh karena stroke menjadikan sindroma depresi semakin berat. Ditambah lagi dengan tanpa adanya dukungan keluarga semakin menjadikan sindroma depresi subjek memiliki prognosis yang buruk.

Saran

Saran yang diberikan untuk konselor atau psikolog yang menangani subjek, diharapkan subjek diberikan psikoterapi katarsis untuk meluapkan semua muatan-muatan negatif traumatis yang 
Philanthrophy Journal of Psychology

Vol 2 Nomor 1 (2018), 1-10

ISSN 2580-6076 (Print), ISSN 2580-8532 (Online)

dialaminya. Salah satu psikoterapi dengan tujuan katarsis emosi adalah art therapy. Selain itu,

diharapkan subjek mengikuti kegiatan rehabilitasi sosial untuk mengembalikan fungsi fisik, mental, sosial subjek yang juga sebagai penyandang disabilitas.

\section{Daftar Pustaka}

Afriani, Ayu. (2015). Pengaruh Yoga terhadap perubahan tingkat depresi pada pecandu narkoba rehabilitasi di Wisma Sirih Rumah Sakit Jiwa Daerah Sungai Bangkong Provinsi Kalimat Barat. Naskah Publikasi. Program Studi Keperawatan, Fakultas Kedokteran, Universitas Tanjung Pura, Pontianak.

Alwisol. (2012). Psikologi Kepribadian Edisi Revisi. Malang: UMM Press.

Azwar, Syaifuddin. 2002. Psikologi Intelegensi. Yogyakarta: Pustaka Pelajar.

Badan Narkotika Nasional Republik Indonesia. 2017. Survei Nasional Penyalahgunaan Narkoba di 34 Propinsi Tahun 2017. Pusat Penelitian Data dan Informasi Badan Narkotika Nasional Republik Indonesia. Diakses di www.BNN.go.id.

Danielson, Carla. K., Overholser, James. C., Butt, Zeeshan A. (2003). Association of Substance Abuse and Depression Among Adolescent Psychiatric Inpatients. Can J Psychiatry. 11(48), $762-765$.

Espada, Jose. P., Sussman, Steve, Medina, T.B.H., Alfonso, J.P., (2011). Relation between Substance Use and Depression among Spanish Adolescents. International Journal of Psychology and Psychological Therapy. 11(1), 79-90.

Feist \& Feist. (2008). Theories Of Personality. Yogyakarta: Pustaka Pelajar.

Kahija, La YF. (2017). Penelitian Fenomenologis Jalan Memahami Pengalaman Hidup. Yogyakarta: PT. Kanisius.

Kurniawan, Yudi \& Sulistyarini, Indahria. (2017). Terapi Kognitif Perilaku Untuk Mengurangi Episode Depresi Berat dengan Gejala Psikotik. Phylantrophy Journal of Psychology. 2017 $1(1), 65-75$.

Maslim, Rusdi, Dr., dr. (2013). Buku Saku Diagnosis Gangguan Jiwa Rujukan Ringkas dari PPGJ III dan DSM - 5. Jakarta: PT. Nuha Jaya.

Mudzkiyyah, L., Nashori, F., Sulistyarini. (2014). Terapi Dzikir al Fatihah untuk Meningkatkan Kesejahteraan Subjektif Pecandu Narkoba dalam Masa Rehabilitasi. https://www.researchgate.net/profile/Fuad_Nashori/publication/313279094.

Noviarini, N.A., Dewi, M.P., Prabowo, H. (2013). Hubungan Antara Dukungan Sosial Dengan Kualitas Hidup Pada Pecandu Narkoba Yang Sedang Menjalani Rehabilitasi. Proceeding PESAT (Psikologi, Ekonomi, Sastra, Arsitektur \& Teknik Sipil). Bandung, 8-9 Oktober 2013 Vol.5, 116-122.

Supriani, Anik. (2011). Tingkat Depresi pada Lansia Di Tinjau Dari Tipe Kepribadian dan Dukukungan Sosial. Tesis (Tidak dipublikasikan). Program Pascasarjana, Universitas Sebelas Maret. Diakses dari https://core.ac.uk/download/pdf/12347568.pdf . 